\title{
THE ECONOMIC IMPACT OF THE VOLKSBLAD ARTS FESTIVAL
}

\author{
AJ Strydom, Central University of Technology, Bloemfontein; M Saayman \& A Saayman, North-West \\ University Potchefstroom
}

\begin{abstract}
Purpose: Arts festivals, as a form of event tourism, are becoming more and more popular in South Africa with new festivals developing annually. The Volksblad Arts Festival in Bloemfontein celebrated its fifth anniversary in 2005. The purpose of this paper is to indicate the economic impact of the annual Volksblad Arts Festival on the local economy of Bloemfontein. Results are also compared with research done at other popular festivals in South Africa.
\end{abstract}

Design/Methodology/Approach: The main thrust of the paper is to determine the economic impact of the Volksblad Arts Festival in Bloemfontein. More than 400 visitor questionnaires and 72 business questionnaires were administered and successfully completed during the festival that took place from 12-17 July 2005.

Findings: The results show that this festival generates R18 405653 . If one compares it to festivals such as the KKNK in Oudtshoorn, the National Arts Festival in Grahamstown and even Aardklop held in Potchefstroom, it is evident that Volksblad is a smaller festival and it is therefore also expected that the economic impact of the festival should be less.

Implications: This paper presents a comprehensive approach to understanding the measurement of the economic impact of a festival like the Volksblad Arts Festival. It provides tourism managers of Bloemfontein with an indication of the potential of event tourism as a source of income for the city. It also indicates the need for more extensive marketing in order to increase the percentage of non-local visitors to the particular festival.

Originality/Value: Bloemfontein is increasingly regarded as an event tourism destination rather than an end destination for leisure tourists. This research represents an original attempt to indicate the potential impact of events to the tourism managers of Bloemfontein as well as other destinations with similar interests.

Key words and phrases: Event tourism; arts festivals; spending patterns; economic impact.

\section{INTRODUCTION AND PROBLEM INVESTIGATED}

Before 1994, the tourism industry in South Africa was almost non-existent, with the contribution thereof to the Gross Domestic Product (GDP) in the vicinity of 2\% (Geldenhuys, 2003:1). Recent statistics indicate that tourism has replaced gold as the major generator of foreign currency for South Africa. Direct spending on tourism generated R 93,6 billion (R15 billion more than gold) for the country in 2004 (Clark, 2006:12). More than 7 million foreign tourists visited South Africa in 2005 in comparison to 600000 in 1992/3. From an employment point of view, the South African tourism industry currently provides 600000 direct and 500000 indirect job opportunities (Clark, 2006:12).

The growth in tourism in South Africa during the past ten years resulted in the development of various types of tourism such as: eco-tourism, cultural tourism, adventure tourism, business tourism, sports tourism, and event tourism. Shone and Parry (2004) emphasise the important role of event tourism in economic terms. In their own words (2004:2): "Indeed, certain events have the purpose of creating wealth or economic value in some way, as well as of entertaining and cementing society".

Event tourism is not a new phenomenon. According to Saayman and Saayman (2004:629), events have been an important feature of people's lives throughout history. Thomas Cook already operated in the mid $19^{\text {th }}$ century as a travel entrepreneur by organising excursions to exhibitions (events) in London and Paris. What has changed in recent times is the frequency, themes and location of events as well as the fact that the events are now presented as significant tourist activities. The aim is to attract a maximum 
number of visitors/tourists and the expenditure associated with it. Tassiopoulos (2000:4) describes event tourism as a truly global sector of the tourism industry.

The emphasis in this article is on the economic analysis of festivals as a form of event tourism. According to Weiler and Hall (1992:69) and Walker and Scott-Melnyk (2002:40), festivals are held to celebrate cultural heritage, historical events, sporting events, religious traditions, etc. One of the main aims of a festival is also to enhance the local tourism industry. The economic importance of events such as festivals is further stressed by Kotler, Bowen and Makens (2006:734) when they mention that: "events and attractions are the two primary strategies used by tourist destinations to attract visitors".

Bloemfontein is situated in the centre of South Africa alongside the N1-highway. The city is not perceived as an end destination for leisure tourists ( $\mathrm{Nel}, 2003: 163)$ and therefore needs to be exposed to other forms of tourism in order to generate positive economic benefits for the local economy. Tourism marketers of the Mangaung Municipality (which includes Bloemfontein, Thaba Nchu and Botshabelo) believe that Bloemfontein is ideally situated and possesses the necessary infrastructure to utilise event tourism as a primary source of income generation (Claassens, 2005).

In light of the above-mentioned, this article aims to analyse the economic impact of the Volksblad Arts Festival in Bloemfontein as a possible means of stimulating the local tourism industry as well as the regional economy as a whole. In this analysis, the following issues are addressed:

- A determination of the demographic profile and total number of festinos;

- A determination of spending patterns of festinos;

- A determination of total income generated during the festival;

- A determination of local versus non-local spending;

- The calculation of the festival's impact on surrounding businesses;

- The calculation of a basic Keynesian multiplier;

- Calculation of the total economic impact of the festival on the local economy.

The article is structured in the following way:

- A literature review on event management in general and festivals in particular;

- A description of the research methodology;

- Discussion of research results (findings);

- Implications/conclusions;

- Recommendations.

\section{LITERATURE REVIEW}

Rural areas, like the Free State (and Bloemfontein), usually have few resources to utilise for development purposes (compare Coetzee, 2004:2). Strydom (1993:135-136) indicated in 1993 already, that the Free State province was in need of a fast-growing industry like tourism to speed-up the economic growth of the province as it was too dependent on the declining mining and agricultural sectors. The situation did not change much and the same need was expressed by Visser and Kotze (2004:17) in 2004. Due to the fact that the Free State (and Bloemfontein as the capital city) cannot be regarded as tourist end destinations, alternative ways of tourism development (event tourism) need to be considered as a generator of tourism and economic growth within the region.

According to Tassiopoulos (2000:5), event tourism could be defined as: "the systematic development, planning, marketing and holding of events such as tourist attractions". Saayman and Saayman (2004:629) identified the following goals of event tourism:

- Increased community pride and spirit; 
- $\quad$ Strengthening of values and traditions;

- Marketing benefits, such as positive image creation;

- Increased community involvement,

- Intercultural interaction;

- Extend the tourism season;

- Economic benefits/impacts.

The economic impact of a special event has been described by Crompton and McKay (as in Daniels and Norman, 2003:214) as: "the net economic change in a host community, excluding non-market values, which results from spending attributable to the event ". Saayman and Saayman (2004:630) argue along the same line when they formulate the economic impact of events as "the net economic change in a host community that results from spending attributed to a cultural event" (also compare Tassiopoulos, 2000:74).

Incorporated in the economic analysis of special events is the multiplier effect, which may be described as a ratio of the effect of tourism spending vis-à-vis the original amount spent (Oppermann \& Chon, 1997:114; Tassiopoulos, 2000:80 and Smith, 1995:16). Income multipliers that relate to the tourism industry are normally relatively high due to the various links between tourism and other industries such as financing, commerce and agriculture. The income multiplier for the tourism industry of South Africa was estimated at 0,68794 in 1992 (Mpekweni Workshop, 1992:6). This implies the creation of R0,68 in the form of indirect and induced income for each R1,00 directly spent in the tourism industry. Other developing countries like Turkey and Egypt recorded income multipliers of 0,96 and 0,23 respectively in 1995 (Oppermann \& Chon, 1997:115).

The size of the multiplier will be affected by the extent of leakages (import propensity). The more the leakages, the lower the multiplier-effect on a local economy will be. According to Oppermann and Chon (1997:114), leakages tend to be high in developing economies due to the following reasons:

- Lack of available goods and services;

- Foreign ownership;

- Vertical integration of tourism suppliers and multinational corporations;

- Lack of skilled labour.

Festivals and events provide various economic benefits such as (Le Grange, 2003:2; Daniels \& Norman, 2003:215; Tassioupoulos, 2000:78 and Shone \& Parry, 2004:54):

- The opportunity for artists to generate income and perform in front of new audiences;

- Financial spin-offs for businesses and the community (such as providers of accommodation, food, entertainment, etc);

- Improved infrastructure;

- Economic revitalisation of the host site;

- Multiplier effects.

Oppermann and Chon (1997:153) also mentioned other benefits such as the high per day expenditure of attendees, improved occupancy rates in shoulder seasons, and the potential to link event tourism with leisure activities such as shopping, dining, etc.

Saayman and Saayman (2004:630) highlight the fact that a growing body of literature indicates that the cost of events may outweigh the benefits. This viewpoint is supported by Le Grange (2003:3) when he states that the financial aspect is one of the biggest challenges to overcome in event planning. Normally, events and festivals are subjected to restricted budgets and high production costs. Another factor that decreases potential profit margins is the fact that festivals are, to a large extent, dependant on local visitors. 
Tassiopoulos (2000:78) points out that a thorough cost-benefit analysis needs to be undertaken before an event like a festival should be considered. Gnoth and Anwar (2000:1) are of opinion that decision-makers should assess events carefully to determine whether they complement the national and/or regional tourism strategy and if they will attract tourists. The following framework may be used to analyse the economic effects of an event (also compare Catherwood \& Van Kirk, 2005:3).

- An analysis of strategic factors that relate to the event;

- A description of the profile of the visitors;

- An analysis of their expenditure profile;

- A determination of the economic and social costs and benefits of the event;

- A description of the profile of the event in terms of sponsorships, media coverage, etc.

Numerous examples of countries that use events as a specific form of tourism can be found. According to Gnoth and Anwar (2000:2), the number of events in New Zealand has increased by $40 \%$ from 1990 to 1997. Researchers in the USA (Daniels \& Norman, 2003:218) calculated the economic impacts of seven regular sport tourism events and came to the conclusion that the events offer great potential for host cities. The 2002 Common Wealth Games, for instance, generated more than 30 million euros in terms of sponsorships and contributed significantly to job creation (Shone \& Parry, 2004:226). In a similar fashion, the economic impact of the 1999 British Open Golf Tournament was estimated at 20 million British pounds (Gelan, 2003:406).

The annual amount of notable events in the form of festivals in South Africa is estimated at more than 30 (Kitshoff, 2004:65). According to Kitshoff, "Festivals seem to have taken root since 1995 in every community in which a feasible need of some sort has been identified". The Klein Karoo National Arts Festival, one of the major festivals of its kind in South Africa, generated approximately R60 million for the local economy in the recent past (www.onair.co.za). In a similar fashion, the economic impact of the Grahamstown National Arts Festival on the Eastern Cape region is profound. An estimated amount of R33 million is brought into the region during the time of the festival (www.gAL.co.za). Aardklop National Arts Festival is estimated to have generated approximately R30 million in 2005 (Saayman \& Saayman, 2005b).

\section{METHODOLOGY}

The method of study included the use of visitor questionnaires and business questionnaires distributed during the Volksblad Arts Festival, which was held from 12-17 July 2005 in Bloemfontein. The methodology is therefore discussed in terms of the surveys and the method.

\section{The Surveys}

A 20-question visitor questionnaire was interviewer-administered at various venues during all the days of the festival and interviewers were chosen randomly. Based on casual observation by the survey team, the respondents were viewed as being representative of the population. In total, 452 visitor questionnaires were administered and sufficiently completed to be used as the sample. Seen in the light that this festival attracts less then 50000 visitors, this can be viewed as a representative sample. The questionnaire included demographic questions as well as questions relating to expenditure during the festival. Key questions included: the number of days and nights spent at the festival; the size of the travel party as well as the number of people who the respondent is paying for; the main reason for being at the festival; as well as attendance of shows.

In addition to the visitor questionnaire, a business questionnaire was also administered. In total, 72 business questionnaires were completed and businesses targeted included mainly those that are closely related to the tourism industry in a radius of $3 \mathrm{~km}$ from the Arts Festival venue. Accommodation facilities (such as guest houses) accounted for $41 \%$ of the respondents, while restaurants, coffee shops and cafés 
accounted for another $43 \%$ of the respondents. The main aim of the business questionnaire was to determine the benefits that these firms derive from the festival and, from an economic impact point of view, to determine the magnitude of leakages from the Bloemfontein area. This information is then used to estimate a sales multiplier effect.

\section{Method}

Basic descriptive statistical analysis was completed to get a better understanding of the demographics of the respondents as well as basic averages. The method used to determine the economic impact of the festival is similar to that described by Gelan (2003) and Saayman and Saayman (2004). In this framework, a distinction is made between festinos from other cities and local festinos. The main rationale behind this is, firstly that the spending pattern of locals differs from that of other festinos, and secondly, because of the debate whether local spending should be included in the analysis (see for example Crompton, 1999; Gelan, 2003 and Saayman \& Saayman, 2004).

The analytical framework applied is indicated in Table 1 and is a slightly adapted version from the one applied by Saayman and Saayman (2004). In this framework, $S_{j}$ denotes spending (S) on different categories (j), $N$ is the total number of tourists, $S_{i}$ is the segment's share in total visits and $\alpha_{i, j}$ is the average spending of a member in segment $i$ on expenditure category $j$. $S_{i}$ consists of two segments, namely locals that attend the festival $\left(L_{s}\right)$ and tourists attending the festival $\left(V_{e}\right)$. $\lambda_{v, j}$ and $\lambda_{1, j}$ represent average expenditure on category $\mathrm{j}$ per tourist and per resident respectively, with $\mathrm{S}$ representing total spending. The sum of spending by the festival coordinating committee on different spending categories $\left(S_{k}\right)$ is also included to capture the expenditure associated with hosting the festival, as proposed by Getz (1991).

Equations (3) and (4) express $L_{s}$ and $V_{e}$ as proportions of total tourists (V) and total residents (L) respectively, since the relative size of each group will only be known after the survey and $\phi$ and $\psi$ thus represent the corresponding ratios. Similarly, the amount of expenditure, $\beta_{\mathrm{v}, \mathrm{j}}$ and $\beta_{\mathrm{l}, \mathrm{j}}$, should be weighted using the proportions that are incurred by the local community, $\delta_{\mathrm{v}, \mathrm{j}}$ and $\delta_{\mathrm{l}, \mathrm{j}}$ and $\delta_{\mathrm{k}}$ (equations 5 and 6 ). By substituting equations (3) to (6) into equation (2), the generalised model is defined (equation 7).

Table 1: System of equations for estimating local economic impact

\begin{tabular}{|c|c|}
\hline Equation description & Number \\
\hline$S_{j}=N \Sigma_{i} S_{i} \alpha_{i, j}$ & (1) \\
\hline $\mathrm{S}=\mathrm{V}_{\mathrm{e}} \Sigma_{\mathrm{j}} \lambda_{\mathrm{v}, \mathrm{j}}+\mathrm{L}_{\mathrm{s}} \Sigma_{\mathrm{j}} \lambda_{1, \mathrm{j}}+\Sigma_{\mathrm{k}} \mathrm{S}_{\mathrm{k}}$ & (2) \\
\hline$V_{e}=\phi V$ & (3) \\
\hline$L_{s}=\psi L$ & (4) \\
\hline$\lambda_{v, j}=\delta_{v, j} \beta_{v, j}$ & $(5)$ \\
\hline$\lambda_{\mathrm{I}, \mathrm{j}}=\delta_{\mathrm{l}, \mathrm{j}} \beta_{\mathrm{l}, \mathrm{j}}$ & (6) \\
\hline$D S=\phi V \Sigma_{j} \delta_{v, j} \beta_{v, j}+\psi L \Sigma_{j} \delta_{1, j} \beta_{1, j}+\Sigma_{k} \delta_{k} S_{k}$ & $(7)$ \\
\hline $\mathrm{TS}=\left(\phi \mathrm{V} \Sigma_{\mathrm{j}} \delta_{\mathrm{V}, \mathrm{j}} \beta_{\mathrm{v}, \mathrm{j}}+\psi \mathrm{L} \Sigma_{\mathrm{j}} \delta_{\mathrm{l}, \mathrm{j}} \beta_{\mathrm{l}, \mathrm{j}}+\Sigma_{\mathrm{k}} \delta_{\mathrm{k}} \mathrm{S}_{\mathrm{k}}\right) \mu$ & (8) \\
\hline
\end{tabular}

Source: Adapted from Saayman and Saayman (2004) and Stynes (1999) 
Equation 7 thus indicates the direct sales effect on the local economy - the most important economic impact indicator in the local study area. The total sales effect, with the indirect and induced affects included, is obtained by multiplying direct sales with the appropriate multipliers $(\mu)$. This is indicated by equation (8) (Saayman \& Saayman, 2004).

To determine the proportion of spending that accrues to the local economy, additional information was obtained from the festival organisers to account for "imported" products sold. The multiplier is derived from the business questionnaire. Although it is very basic, it is an attempt to get a more realistic view of the magnitude of the indirect and induced effects. The multiplier can be viewed as a sales multiplier that indicates "the additional local economic impacts as monies are re-spent by local merchants to purchase supplies and services" (Pollock et al., 1994).

\section{FINDINGS}

The results are discussed in three sections, namely: the demographics of the festinos; the spending pattern of festinos (as this is the most important input in the economic analysis); and lastly the economic impact, as determined with the above-mentioned analytical framework.

\section{Demographics}

Based on the information gathered via the questionnaire, it can be deducted that festinos to Volksblad Arts Festival are predominantly female and Afrikaans-speaking. It is also a festival that is widely supported by the local population, as is evident from the $70 \%$ of the respondents that were locals. The average visitor to the festival spent more than 3 days at the festival and travelled in parties of approximately 3 persons. An average of 2.2 tickets are bought by the travel party for attending ticketed shows. These demographic details are summarised in Table 2.

\section{Table 2: Demographics of festinos}

\begin{tabular}{|l|l|}
\hline Demographic & Volksblad \\
\hline Male / Female & $62 \%$ Female \\
& $38 \%$ Male \\
\hline Language & $94 \%$ Afrikaans \\
\hline Respondent breakdown & $70 \%$ locals \\
& $30 \%$ visitors \\
\hline Length of festival & 6 days \\
\hline Length of stay & 3.3 days \\
\hline Travel party & 2.8 \\
\hline Average number of tickets bought per group & 2.2 \\
\hline Total tickets sold & 27671 \\
\hline
\end{tabular}

\section{Spending Pattern}

It was already indicated that the spending pattern of locals differ from that of visitors. Locals, for example, do not spend on accommodation. The spending pattern of local festinos and that of visitors are indicated in Table 3. 
Table 3: Spending by festinos (per festino)

\begin{tabular}{|l|l|l|}
\hline Item & Visitors & Locals \\
\hline Accommodation & $\mathrm{R} 17.74$ & - \\
\hline Food \& Restaurant & $\mathrm{R} 54.68$ & $\mathrm{R} 39.51$ \\
\hline Alcohol & $\mathrm{R} 26.25$ & $\mathrm{R} 20.25$ \\
\hline Non-alcoholic & $\mathrm{R} 12.33$ & $\mathrm{R} 10.00$ \\
\hline Tobacco & $\mathrm{R} 2.85$ & $\mathrm{R} 2.53$ \\
\hline Shows & $\mathrm{R} 57.65$ & $\mathrm{R} 61.40$ \\
\hline Shopping & $\mathrm{R} 39.79$ & $\mathrm{R} 33.10$ \\
\hline Souvenirs & $\mathrm{R} 28.89$ & $\mathrm{R} 28.42$ \\
\hline Transport to festival & $\mathrm{R} 87.02$ & $\mathrm{R} 1.48$ \\
\hline Transport during festival & $\mathrm{R} 7.62$ & $\mathrm{R} 3.30$ \\
\hline Parking & $\mathrm{R} 0.29$ & $\mathrm{R} 0.04$ \\
\hline Other & $\mathrm{R} 0.91$ & $\mathrm{R} 10.03$ \\
\hline Total & $\mathrm{R} 336.04$ & $\mathrm{R} 210.05$ \\
\hline
\end{tabular}

It is evident from Table 3 that visitors spend more on all items than locals, except for "other" spending, and that visitor spending is approximately 50 percent more than that of local spending. The item most money is spent on is transport to the festival, while spending on show tickets accounts for a large percentage of total spending. The low spending of visitors on accommodation is an indication that many visitors stay with family and friends in the Bloemfontein vicinity. Another interesting observation is the spending of "locals" on transport to the festival. This might be due to students returning from their parents' homes to visit the festival, and although they count as locals in that sense of the word, it is evident that many locals actually "holiday" at the festival. Again this emphasises the difficulty of excluding local spending from the analysis.

\section{Economic Impact}

Based on the number of tickets sold, the average price of tickets, and the spending per person on tickets, it is estimated that 26709 festinos attended the festival. Most of them attended not only one day, but an average of 3.3 days, resulting in a total number of visitor days of 88139 (i.e. in this method, a visitor attending 3 days is counted three times). The survey revealed that $70 \%$ of all festinos are locals, resulting in 18696 festinos from the Bloemfontein area. Note that Table 4 indicates that some of the visitors (37\%) that spent time at the festival were not in the Bloemfontein area solely for the purpose of the festival. While it may be debated whether their spending should be included or not, the authors do feel that they have contributed to spending at the festival and their spending is thus also included in further analysis.

Table 4: Total number of festinos and distribution of festinos

\begin{tabular}{|l|l|}
\hline & Volksblad Arts Festival \\
\hline Total number of festinos $(\mathrm{N})^{\prime}$ & $26709(100 \%)$ \\
$\quad$ Visitors $(V)$ & $8013(30 \%)$ \\
Locals $\left(L_{s}\right)$ & $18696(70 \%)$ \\
Visitor breakdown & \\
Due to event $(\phi)$ & $5074(63 \%)$ \\
Other reasons $(1-\phi)$ & $2938(37 \%)$ \\
Visitor days & 88139 \\
\hline
\end{tabular}


Using equation (2) and the information described above and in Table 3, total spending by festinos is estimated at R6 619 788. If one adds the spending by festival organisers (sponsorships received is taken as the proxy) and the rent received from exhibitors, the total spending that took place due to the festival is estimated at R8 749788.

Yet, not all of this spending occurs in the Bloemfontein-area. For example, transport costs to the festival often take place at the origin city and most ticket sales take place before the festival. One should also keep in mind that many of the items spent on are not offered by locals. In this regard, spending on souvenirs is a good example, since many souvenir stall owners reside outside the Bloemfontein area. This is also true for show tickets. Many artists originate from outside Bloemfontein and a large proportion of ticket sales are used for their remuneration.

Ratios $\left(\delta_{\mathrm{v}, \mathrm{j}}\right.$ and $\left.\delta_{\mathrm{l}, \mathrm{j}}\right)$ are thus applied to the above-mentioned cases to correct for these incorrect inclusions in total sales. The ratios used are 0.5 for transport to the festival (based on the premise that people fill their cars before leaving home and again before leaving Bloemfontein), 0.5 for souvenirs (based on information from festival organisers that $50 \%$ of stall owners were from outside the area) and 0.234 for show tickets (also based on festival organiser information on remuneration of artists). It is also true that not all spending by festival organisers accrue to the local area. Based on information provided by the festival organisers, it is estimated that $80 \%$ of their spending accrues to the area. The ratio applied $\left(\delta_{k}\right)$ is thus 0.8 .

In Table 5, the estimated total direct expenditure by locals and visitors that accrue to the local area is specified according to expenditure category. It is evident that the total direct spending by locals exceeds that of visitors, and this can be attributed to the magnitude of the local market relative to visitors, that attend the festival.

Table 5: Estimated local expenditure (R) according to category for the festival

\begin{tabular}{|l|l|l|}
\hline Category & Locals & Visitors \\
\hline Accommodation & 0 & 142138.81 \\
\hline Food \& Restaurant & 738670.62 & 438150.45 \\
\hline Alcohol & 378504.69 & 210365.44 \\
\hline Non-alcoholic & 187049.31 & 98807.64 \\
\hline Tobacco & 47275.87 & 22863.18 \\
\hline Shows & 268601.32 & 108103.64 \\
\hline Shopping & 618784.01 & 318874.82 \\
\hline Souvenirs & 265703.50 & 115767.53 \\
\hline Transport to festival & 13798.72 & 348633.24 \\
\hline Transport during festival & 61684.89 & 61089.45 \\
\hline Parking & 774.04 & 2322.61 \\
\hline Other & 187555.41 & 7258.15 \\
\hline Total & $\mathbf{2 7 6 8 \mathbf { 4 0 2 . 4 0 }}$ & $\mathbf{1 8 7 4 3 7 4 . 9 8}$ \\
\hline
\end{tabular}

Based on the above and the ratio that is applied to festival organiser spending, the direct sales effect of the festival (equation (7)) is estimated at R6 346 777. It is therefore evident that almost R2.4 million of total expenditure does not take place in the local area and thus the direct sales effect is less than the total expenditure. This direct sales effect is the first round of funds that accrue to the local area. To determine the indirect and induced effects, a multiplier must be applied. 
As indicated in the methodology, the business questionnaire was designed to determine the magnitude of leakages from the Bloemfontein economy. The following table (Table 6) indicates the average leakages, in terms of stock bought from outside the area, of different types of businesses. Table 6 shows the number of respondents in each type of business as well as the average percentage of stock that is bought outside the area. It is evident that accommodation units have a very low stock leakage factor, while petrol stations exhibit high leakages.

Table 6: Average leakages according to business type

\begin{tabular}{|l|l|l|}
\hline Type of business & Number of respondents & $\begin{array}{l}\text { Average percentage of stock } \\
\text { bought outside the area }\end{array}$ \\
\hline Accommodation & 29 & $10.95 \%$ \\
\hline Café/Take away & 13 & $33.75 \%$ \\
\hline Bar/Bottle store & 6 & $24.17 \%$ \\
\hline Restaurant & 18 & $43.28 \%$ \\
\hline Petrol station & 6 & $48.00 \%$ \\
\hline
\end{tabular}

This information is applied as the input to the multiplier used in the analysis. The basic Keynesian multiplier definition is applied as a rough estimate of the value of the multiplier. The multiplier is derived by means of the following formulae: Multiplier $=1 /$ leakages, where the weighted average leakages (as determined by the business surveys) are used as the proxy leakages. The weights applied are determined based on relative importance of the spending item in total spending. The weighted average stock leakages are estimated at $34.1 \%$ of stock. The multiplier applied in this instance is thus 2.9 , which is a very large multiplier and it should thus only be treated as an estimate. Given this multiplier, the total sales effect (equation (8)) and thus the economic impact of the festival on the Bloemfontein economy is estimated at R18 405653.

\section{CONCLUSION}

If one compares the Volksblad Arts Festival to festivals such as the KKNK in Oudtshoorn, the National Arts Festival in Grahamstown and even Aardklop held in Potchefstroom, it is evident that Volksblad is a much smaller festival and it is therefore also expected that the economic impact of the festival should be less.

By distinguishing between spending by locals and that of visitors from outside the area, this article places the economic impact of the Volksblad Arts Festival into perspective and contributes towards a better understanding of the importance of local communities in arts festivals. It is often argued that local spending should not be included in the economic impact derivation, since the spending would have taken place in the area anyway and the festival just causes a distortion of the normal spending pattern by locals. Crompton (1999) argues that local spending could be included if it is viewed that the locals are "holidaying" at the festival, that is, not going somewhere else in the time period of the festival but rather staying home to enjoy the festival. The inclusion of local spending can over-inflate the impact of the festival, but omitting local spending presents misleading results in terms of the true value of the festival for the area. Seen in this light, Gelan (2003) and Saayman and Saayman (2004) included spending by locals, since it was felt that many locals "holiday" at the event.

In a case such as the Volksblad Arts Festival where $70 \%$ of festinos are locals, it becomes even more important to debate the benefit of such a festival to the local economy and area. Most of the other festivals mentioned above have a smaller percentage of local festinos relative to total festinos than the Volksblad festival. Additionally, even though festinos from outside the local area spend more per person than local festinos, it does not mean that the festival cannot be regarded as an important economic event 
for the area. The festival created an opportunity for locals to spend money in the area in the short run, thereby accelerating economic activity in the area. If this is analysed further, it is also important to note that a wider variety of people and organisations benefit from the festival. Under normal circumstances, meals would, for example, be bought from a limited number of restaurants, while the festival creates the opportunity to expand the choices of consumers and spending to spread to other organisations and suppliers. While previous research has proven that most of the employment created during a festival is mostly temporary, it should be noted that the categories spent on are mostly labour-intensive industries (accommodation, food and restaurants). When this is taken into account, it places the importance of the festival for the economy in more perspective, even though it is mainly supported by locals.

While the focus of this article is on the economic impact, other benefits of this festival for Bloemfontein should not be neglected. A major benefit is that the festival takes place in July, which is out of season for tourism to the Free State Province and Bloemfontein specifically, which supports the literature in the sense that events can be used to address seasonality in tourism demand. This festival also has marketing benefits by creating a positive image of the city; it attracts investment, builds community relations and brings arts to the community.

\section{RECOMMENDATIONS}

The following recommendations can be made:

Firstly, the magnitude of the economic impact can be increased by offering more local products and services from the area. Secondly, this article highlights the importance of local community involvement, and the festival should be promoted more actively in the Bloemfontein area. Thirdly, visitors from outside the area normally spend more, especially from the Gauteng Province, and efforts should be made to attract more festinos from this province (see Saayman \& Saayman, 2005a). Yet, in order to achieve sustainability, the economic objectives need to be balanced with the other objectives of the festival, such as social or cultural development.

\section{REFERENCES}

Catherwood DW \& Van Kirk RL. 2005. The complete guide to special event management. John Wiley and Sons.

Claassens G. 2006. Personal Interview, 5 July 2006.

Clark J. 2005. SA wil groter hap van toerismekoek kry. Die Volksblad, 13 Februarie 2006.

Coetzee WJL. 2004. An integrated sustainable tourism development strategy for the Vredefort Dome as a world heritage site. Potchefstroom: North West University. (Unpublished PhD-thesis).

Crompton J. 1999. Measuring the Economic Impact, Working Paper [Online] Available from: http://rptsweb.tamu.edu/faculty/crompton.htm.

Daniels MJ \& Norman WC. 2003. Estimating the economic impacts of seven regular sport tourism events. Journal of Sport Tourism, 8(4):214-222.

Geldenhuys S. 2003. An ecotourism curriculum for higher education institutions. Potchefstroom: Potchefstroomse Universiteit vir Christelike Hoër Onderwys. (Unpublished PhD-thesis).

Gelan A. 2003. Local Economic Impacts: The British Open. Annals of Tourism Research, 30(2):406425. 
Getz D. 1991. Assessing the Economic Impacts of Festivals and Events: Research Issues. Journal of Applied Research, 16(1):61-77.

Gnoth J \& Anwar SA. 2000. New Zealand bets on event tourism. Cornell Hotel and Restaurant Administration Quarterly, 41(4):72-83, August.

Kitshoff H. 2004. Claiming cultural festivals: playing for power at the Klein Karoo Nasionale Kunstefees (KKNK). South African Theatre Journal, 18:65-81.

Kotler P, Bowen JT \& Makens JC. 2006. Marketing for Hospitality and Tourism. $4^{\text {th }}$ ed. Pearson Education Ltd.

Le Grange R. 2003. The impact of the Aardklop festival on the local economy. Pretoria: University of Pretoria (Unpublished Masters-thesis).

Mpekweni Workshop. 1992. Proceedings of the workshop on Support Programmes for the Tourism Industry within the ECOSA States. Ciskei. Compiled with the original assistance of E van Dijk.

Nel RG. 2003. The tourism image of Bloemfontein as perceived by tour operators in certain metropolitan areas of South Africa. Unpublished M Tech-dissertation.

Oppermann M \& Chon KS. 1997. Tourism in developing countries. Thomson Business Press.

Pollock KH, Jones CM \& Brown TL. 1994. Angler Survey methods and their application in Fisheries Management. American Fisheries Society Special Publication, 25:255-266.

Saayman M \& Saayman A. 2004. Economic impact of cultural events. South African Journal of Economic and Management Sciences, 7(4):629-633.

Saayman M \& Saayman A. 2005a. Markprofiel en Ekonomiese Impak van die Klein Karoo Nasionale Kunstefees. Potchefstroom: Instituut vir Toerisme en Vryetydstudies.

Saayman M \& Saayman A. 2005b. Markprofiel en Ekonomiese Impak van die Aardklop Nasionale Kunstefees. Potchefstroom: Instituut vir Toerisme en Vryetydstudies.

Shone A \& Parry B. 2004. Successful event management. London: Thomson.

Smith SLJ. 1995. Tourism Analysis: a handbook. $2^{\text {nd }}$ ed. Longman Group Limited.

Strydom AJ. 1993. ' $n$ Strategiese plan vir die efffektiewe benutting van die toerismepotensiaal van die Oranje-Vrystaat. Bloemfontein: Universiteit van die Oranje-Vrystaat, Instituut vir Sosiale en Ekonomiese Navorsing.

Stynes D. 1999. Economic Impact Concepts and Methods [Online] Available from: http://www.msu.edu/rstynes/.

Tassiopoulos D (ed). 2000. Event management: a professional and developmental approach. Cape Town: Juta.

Visser G \& Kotze N. 2004. Towards a tourism development strategy for the Free State Province. Bloemfontein: University of the Free State (Unpublished report).

Walker C \& Scott-Melnyk S. 2002. How and why people participate in arts and culture. American Urban Institute. 
Weiler B \& Hall CM (ed). 1992. Special Interest Tourism. London: Belhaven Press.

\section{Websites}

http://www.gaL.co.za

http://www.onair.co.za

'The appropriate symbol, as defined in Table 1, is indicated in brackets. Note that locals are already accepted as being a weighted population $\left(L_{s}=\psi L\right)$, since the question was phrased so as to ask about the additional spending due to the festival. 